\title{
Increased breast cancer cell toxicity by palladination of the polyamine analogue $N^{1}, N^{11}$-bis(ethyl)norspermine
}

\author{
Tania M. Silva $\cdot$ Sonia M. Fiuza $\cdot$ Maria P. M. Marques • \\ Lo Persson $\cdot$ Stina Oredsson
}

Received: 1 August 2013/Accepted: 3 November 2013/Published online: 21 December 2013

(c) The Author(s) 2013. This article is published with open access at Springerlink.com

\begin{abstract}
Breast cancer is one of the most common malignant tumor forms among women and many women succumb to their disease. Thus, new anticancer agents that can efficiently improve patient survival are of the utmost importance. In this study, the effects of the polyamine analogues $N^{1}, N^{11}$-bis(ethyl)norspermine (BENSpm) and $N^{1}$-cyclo-propylmethyl- $N^{11}$-ethylnorspermine (CPENSpm) and the synthesized dinuclear complexes $\mathrm{Pd}_{2} \mathrm{BENSpm}(\mathrm{Pd}-$ BENSpm), $\mathrm{Pt}_{2}$ CPENSpm (Pt-CPENSpm) and $\mathrm{Pd}_{2} \mathrm{Spm}(\mathrm{Pd}-$ $\mathrm{Spm})$ were investigated in normal-like breast epithelial MCF-10A cells and the breast cancer cell lines JIMT-1 and L56BR-C1. The overall data show that palladination of BENSpm resulted in enhanced cytotoxicity, in contrast to platination of CPENSpm that reduced cytotoxicity, which might be explained by differences in the cellular uptake of Pd-BENSpm and Pt-CPENSpm. BENSpm and Pd-BENS$\mathrm{pm}$ treatment reduced the $\mathrm{CD} 44^{+} \mathrm{CD} 24^{-}$putative cancer stem cell population, evaluated by flow cytometry.
\end{abstract}

Electronic supplementary material The online version of this article (doi:10.1007/s00726-013-1621-y) contains supplementary material, which is available to authorized users.

T. M. Silva ( $\square)$ · S. M. Fiuza · M. P. M. Marques

Research Unit "Molecular Physical-Chemistry", University

of Coimbra, Coimbra, Portugal

e-mail: taniamaga12@gmail.com

T. M. Silva $\cdot$ S. Oredsson

Department of Biology, University of Lund, Lund, Sweden

T. M. Silva · L. Persson

Department of Experimental Medical Science, University

of Lund, Lund, Sweden

M. P. M. Marques

Department of Life Sciences, Faculty of Science and

Technology, University of Coimbra, Coimbra, Portugal
Furthermore, Pd-BENSpm was the most efficient compound regarding induction of DNA damage and decrease in colony formation in soft agar. Pt-CPENSpm and Pd-Spm, on the other hand, were shown to be the least toxic compounds of all tested. Pd-Spm efficiently reduced the cellular glutathione levels, which probably was a consequence of its metabolic inactivation by conjugation to this endogenous thiol. The normal-like cells were found to be less sensitive to the agents than the breast cancer cells. Our findings show that Pd-BENSpm exhibits promising anticancer effects which render it suitable for further optimization to develop a new metal-based chemotherapeutic drug for breast cancer treatment.

Keywords Breast cancer - Polyamine analogues . Palladium (Pd)(II) complexes · Platinum (Pt)(II) complexes - DNA damage - Cancer stem cells

\begin{tabular}{|c|c|}
\hline \multicolumn{2}{|l|}{ Abbreviations } \\
\hline BENSpm & $N^{1}, N^{11}$-bis(ethyl)norspermine \\
\hline CFE & Colony forming efficiency \\
\hline CPENSpm & $\begin{array}{l}N^{1} \text {-Cyclo-propylmethyl- } N^{11} \text { - } \\
\text { ethylnorspermine }\end{array}$ \\
\hline $\mathrm{CSC}$ & Cancer stem cell \\
\hline DMSO & Dimethyl sulphoxide \\
\hline FCM & Flow cytometry \\
\hline FCS & Fetal calf serum \\
\hline FITC & Fluorescein isothiocyanate \\
\hline GSH & Glutathione \\
\hline ICP-MS & $\begin{array}{l}\text { Inductively-coupled plasma mass } \\
\text { spectrometry }\end{array}$ \\
\hline MTT & $\begin{array}{l}\text { 3-(4,5-Dimethyl-thiazolyl-2)-2,5 } \\
\text { diphenyltetrazolium bromide }\end{array}$ \\
\hline NSpd & Norspermidine \\
\hline PBS & Phosphate-buffered saline \\
\hline
\end{tabular}




$\begin{array}{ll}\text { Pd } & \text { Palladium } \\ \text { Pd-BENSpm } & \mathrm{Pd}_{2} \text { BENSpm } \\ \text { Pd-Spm } & \mathrm{Pd}_{2} \mathrm{Spm} \\ \mathrm{PE} & \text { Phycoerythrin } \\ \text { PI } & \text { Propidium iodide } \\ \text { polyHEMA } & \text { poly(2-hydroxyethyl methacrylate) } \\ \text { Pt } & \text { Platinum } \\ \text { Pt-CPENSpm } & \mathrm{Pt}_{2} \text { CPENSpm } \\ \text { SCGE } & \text { Single cell gel electrophoresis } \\ \text { SSAT } & \text { Spermidine/spermine } N^{1} \text {-acetyltransferase }\end{array}$

\section{Introduction}

The antiproliferative features of cisplatin, [cis-diamminedichloroplatinum (II)], (cis- $\mathrm{Pt}\left(\mathrm{NH}_{3}\right)_{2} \mathrm{Cl}_{2}$ ), were discovered in 1965 by Barnett Rosenberg and resulted in the successful use of this compound, as the first metal complex, in the treatment of a wide range of solid tumors (Rosenberg et al. 1965). Platinum (Pt)-based agents are widely used as chemotherapeutic compounds in today's oncological practice, based on their ability to enter the cell nucleus and covalently bind to DNA, yielding stable adducts (Brabec and Kasparkova 2005; Esteban-Fernandez et al. 2010). The formation of several cross-links with DNA leads to a distortion of the DNA molecule. Thus, essential biological processes, such as replication and transcription of DNA are inhibited, which affects protein synthesis and, consequently, cell proliferation (Brabec and Kasparkova 2005; Esteban-Fernandez et al. 2010). Problems with off-target effects such as neurotoxicity and nephrotoxicity, and the development of acquired resistance, are the main limiting factors of cisplatin treatment (Brabec and Kasparkova 2005; Esteban-Fernandez et al. 2010). In the few last years, palladium (Pd)(II) complexes have shown significant antitumor activity against different cancer cell lines, along with fewer off-target effects, as compared to cisplatin (Ulukaya et al. 2011).

Another group of compounds extensively used in experimental cancer research are polyamine analogues (Casero and Woster 2009). The natural polyamines putrescine, spermidine and spermine are a group of ubiquitous positively charged substances with low molecular weight (Wallace et al. 2003; Palmer and Wallace 2010). In all eukaryotic cells, the polyamines are involved in a large number of fundamental biological processes, such as in the regulation of cell proliferation, differentiation and death (Wallace et al. 2003; Palmer and Wallace 2010; Traquete et al. 2013). Although all of the exact roles of polyamines in these processes are not known, the capacity to interact with DNA and affect DNA conformation are thought to play a role in their normal cellular function (Iacomino and Picariello 1823; Pasini et al. 2013). Polyamine pools are in general higher in malignant tissue than in normal tissue (Pegg 1988; Traquete et al. 2013), which has suggested the polyamine metabolic pathway as a target for anticancer therapy (Pegg 1988; Seiler 2005; Casero and Woster 2009; Palmer and Wallace 2010). Polyamine pool depletion results in inhibition of cell proliferation and, sometimes, in induction of cell death. One means to achieve polyamine depletion is to treat with polyamine analogues, which stimulate polyamine catabolism and inhibit polyamine biosynthesis, while they cannot functionally substitute for the depleted biogenic polyamines (Davidson et al. 1999; Oredsson et al. 2007; Casero and Woster 2009). Among the most promising studied polyamine-based antitumor compounds are the $N$-ethyl-substituted polyamines, such as $N^{1}, N^{11}$ bis(ethyl)norspermine (BENSpm), a symmetrically substituted spermine analogue and $N^{1}$-cyclo-propylmethyl$N^{11}$-ethylnorspermine (CPENSpm), an unsymmetrically substituted spermine analogue. They have been found to down-regulate polyamine biosynthesis, up-regulate catabolism and compete for polyamine uptake, resulting in dramatic polyamine depletion, inhibition of cell proliferation and, sometimes, induction of apoptosis (Davidson et al. 1999; Casero and Woster 2009).

A way to increase the efficiency of a chemotherapeutic agent, e.g. by increasing interaction with DNA, may be to combine two different compounds for which DNA is the biological target, for instance $\mathrm{Pt}(\mathrm{II})$ and $\mathrm{Pd}(\mathrm{II})$ complexes with polyamine ligands. In fact, linear alkylpolyamines are suitable ligands for both $\mathrm{Pt}(\mathrm{II})$ and $\mathrm{Pd}(\mathrm{II})$ ions, and yield polynuclear chelates capable of disrupting the native DNA conformation through the formation of non-conventional (long-range, interstrand) interactions with the $\mathrm{N}_{7}$ atom of the purine bases (Hegmans et al. 2008; Ulukaya et al. 2011). Several promising results with these complexes have been obtained over the last years (Lebwohl and Canetta 1998; Marques et al. 2002; Fiuza et al. 2006; Fiuza et al. 2011; Miklasova et al. 2012; Silva et al. 2012).

We have shown that several breast cancer cell lines are highly sensitive to treatment with the $\mathrm{Pd}(\mathrm{II})$ chelate of the polyamine analogue norspermidine (NSpd) and that this chelate was more toxic than its Pt(II) counterpart (Silva et al. 2013). Also, a palladinated spermine was found to be cytotoxic against breast cancer cell lines (Fiuza et al. 2011).

In the present study, we investigate the cytotoxic effects of several $\mathrm{Pd}(\mathrm{II})$ and $\mathrm{Pt}(\mathrm{II})$ polyamine complexes against two human breast cancer cell lines (JIMT-1 and L56Br-C1) and one immortalized normal-like breast epithelial cell line (MCF-10A): two newly synthesized Pd(II) and Pt(II) chelates $\mathrm{Pd}_{2} \mathrm{BENSpm}$ (Pd-BENSpm) and $\mathrm{Pt}_{2} \mathrm{CPENSpm}$ (PtCPENSpm) (Silva et al. 2012)-and the complex $\mathrm{Pd}_{2} \mathrm{Spm}$ (Pd-Spm). Altogether, the results show that palladination of 
BENSpm resulted in an increased cytoxicity relative to the other tested compounds.

\section{Materials and methods}

\section{Chemicals}

Cell culture medium components were purchased from Biochrom, Berlin, Germany. Tissue culture plastics were acquired from Nunc, Roskilde, Denmark. Phosphate-buffered saline (PBS: $8 \mathrm{~g} / \mathrm{L} \mathrm{NaCl}, 0.2 \mathrm{~g} / \mathrm{L} \mathrm{KCl}, 1.15 \mathrm{~g} / \mathrm{L}$ $\mathrm{Na}_{2} \mathrm{HPO}_{4}, 0.2 \mathrm{~g} / \mathrm{L} \mathrm{KH}_{2} \mathrm{PO}_{4}, \mathrm{pH} 7.3$ ) was purchased from Oxoid Ltd., Basingstoke, Hampshire, UK. Nonidet P-40 was purchased from VWR, Lund, Sweden. Insulin, hydrocortisone, propidium iodide (PI), Accutase, 3-(4,5-dimethylthiazolyl-2)-2,5 diphenyltetrazolium bromide (MTT) and poly(2-hydroxyethyl methacrylate) (polyHEMA) were obtained from Sigma, Stockholm, Sweden. Epithelial growth factor was purchased from Invitrogen AB, Stockholm, Sweden. Dimethyl sulphoxide (DMSO) was acquired from Merck KGaA, Darmstadt, Germany. ${ }^{14}$ [C]Acetyl-coenzyme A was purchased from New England Nuclear, DuPont, Scandinavia AB, Stockholm, Sweden. The monoclonal antibodies CD44-fluorescein isothiocyanate (FITC) and CD24-phycoerythrin (PE) together with the FITC- and PEconjugated mouse IgG1 isotype controls were obtained from Becton-Dickinson, Stockholm, Sweden. Nusieve ${ }^{\circledR}$ GTG low-melting-point agarose, agarose gel supporting medium and Gel Bond ${ }^{\circledR}$ membranes were obtained from FMC BioProducts, Rockland, ME, USA. The GSH-Glo ${ }^{\text {TM }}$ Glutathione (GSH) kit was purchased from Promega Biotech AB, Nacka, Sweden. The Pd-Spm complex was synthesized by Dr. Sónia Fiuza (Fiuza et al. 2011). BENSpm and CPENSpm were synthesized and kindly provided by Dr. Patrick Woster, Department of Drug Discovery and Biomedical Sciences, Medical University of South Carolina, USA (Casero and Woster 2009). Pd-BENSpm and Pt-CPENSpm complexes were synthesized as previously described (Silva et al. 2012). The complexes are fully characterized by elemental analysis, as well as through vibrational spectroscopy (Raman and FTIR). The purity of the analyzed compounds is therefore assured (Silva et al. 2012).

\section{Drug stock solutions}

Stock solutions ( $2 \mathrm{mM}$ ) of BENSpm and CPENSpm were made in PBS, sterile-filtered and stored at $4{ }^{\circ} \mathrm{C}$. $\mathrm{Pd}-$ BENSpm and Pd-Spm were dissolved in $4 \%$ DMSO in PBS to give stock solutions of $1 \mathrm{mM}$ that were sterilefiltered and stored at $-20{ }^{\circ} \mathrm{C}$. Pt-CPENSpm was dissolved in $4 \%$ DMSO in PBS to give a stock solution of $2 \mathrm{mM}$, sterile-filtered and stored at $-20{ }^{\circ} \mathrm{C}$. Further dilutions were made in complete cell culture medium to give the final concentrations.

Cell lines and cell culturing

The L56Br-C1 cell line was established at the Department of Oncology, Clinical Sciences, Lund University, Sweden (Johannsson et al. 2003). The JIMT-1 cell line was purchased from the German Collection of Microorganisms and Cell Cultures (Braunschweig, Germany) and the MCF-10A cell line was obtained from the American Tissue Type Culture Collection (Manassas, VA, USA). The cell lines were cultured as previously described (Silva et al. 2013). For all experiments, the cells were seeded and allowed to attach and grow for $24 \mathrm{~h}$, before addition of compound at a $10 \mu \mathrm{M}$ concentration. A concentration range between 0.1 and $100 \mu \mathrm{M}$ was used in the MTT assay. The control received DMSO at the same final concentration as that in the treated cultures, i.e., $0.1-0.2 \%$.

\section{Dose response assay}

The MTT assay was performed as previously described (Holst and Oredsson 2005). Briefly, cells were seeded in 96-well microplates with a seeding density of 3,000 (MCF10A), 5,000 (JIMT-1) or 8,000 (L56Br-C1) cells in $180 \mu \mathrm{l}$ of medium. At 24, 48 and $72 \mathrm{~h}$ of drug treatment, $20 \mu \mathrm{l}$ of MTT solution ( $5 \mathrm{mg} / \mathrm{ml}$ MTT in PBS) was added to the cells, which were incubated for $1 \mathrm{~h}$ at $37^{\circ} \mathrm{C}$. After removal of the MTT containing medium, the cells containing insoluble formazan crystals were dissolved by addition of $100 \mu \mathrm{l}$ of $100 \%$ DMSO per well. Absorbance was monitored at $540 \mathrm{~nm}$ in a Labsystems iEMS Reader MF (Labsystems Oy, Helsinki, Finland) using the DeltaSoft II v.4.14 software (Biometallics Inc., Princeton, NJ, USA).

\section{Cell proliferation}

Cells were seeded in Petri dishes $(5 \mathrm{~cm}$ diameter $)$ at a density of $0.3 \times 10^{6}$ cells/Petri dish (MCF-10A cells) or $0.6 \times 10^{6}$ cells/Petri dish (JIMT-1 and L56Br-C1 cells) in $5 \mathrm{ml}$ of medium. The cells were allowed to attach and grow for $24 \mathrm{~h}$ and were further harvested by trypsinization, with the cell number being determined by counting in a hemocytometer after 24,48 and $72 \mathrm{~h}$ of treatment.

Effect of long-time exposure on cell proliferation

This experiment was design to investigate the effect of the tested compounds on cancer cell proliferation over a longer period and was performed as previously described (Silva et al. 2013). Cells $\left(0.3 \times 10^{6} \mathrm{MCF}-10 \mathrm{~A}\right.$ cells, $0.7 \times 10^{6}$ JIMT- 1 cells and $0.7 \times 10^{6} \mathrm{~L} 56 \mathrm{Br}-\mathrm{C} 1$ cells) were seeded 
into $5 \mathrm{ml}$ of medium in $25 \mathrm{~cm}^{2}$ cell culture flasks and the compounds were added to the final concentration of $10 \mu \mathrm{M}$ $24 \mathrm{~h}$ later. At each passage, cells were harvested by trypsinization, counted in a hemocytometer, and reseeded at the same density as above. The cells received the same treatment during each passage. Each week of treatment is defined as a treatment cycle and the cells were subjected to five treatment cycles. The total recovery time, i.e., incubation without compound, was $96 \mathrm{~h}$. The data are presented as the total amount of cells that theoretically would have accumulated if all cells had been reseeded with a known cell density after each treatment cycle. Thus, using the cell number obtained at each passage of a culture seeded with a known cell density, and applying the formula $\log N=\log N_{0}+n \log 2$, it was possible to calculate the number of cells that would have been obtained if all cells were reseeded at a lower density at each passage.

Intracellular Pd(II) and Pt(II) accumulation

For the study of the intracellular accumulation of Pd-BENSpm, Pd-Spm or Pt-CPENSpm, cells $\left(1 \times 10^{6}\right.$ MCF-10A cells and $2 \times 10^{6}$ JIMT- 1 and L56Br-C1 cells) were seeded into $12 \mathrm{ml}$ of medium in Petri dishes $(9 \mathrm{~cm}$ diameter). After $72 \mathrm{~h}$ of treatment with a $10 \mu \mathrm{M}$ concentration of the tested compounds, cells were washed with ice-cold PBS, harvested by trypsinization, counted, pelleted by centrifugation and stored at $-80{ }^{\circ} \mathrm{C}$ until analysis. Prior to analysis, the pellets were digested in $65 \% \mathrm{HNO}_{3}$ for $2 \mathrm{~h}$ at $65{ }^{\circ} \mathrm{C}$, diluted to a $5 \%$ acid solution and centrifuged at $600 \mathrm{~g}$ for $14 \mathrm{~min}$. The $\mathrm{Pd}(\mathrm{II})$ and $\mathrm{Pt}(\mathrm{II})$ accumulation was then analyzed by inductively-coupled plasma mass spectrometry (ICP-MS) (Thermo X7, Thermo Elemental, Winsford, UK). The data of metal content were used to calculate the intracellular concentration of the compounds.

Analysis of polyamine content by high performance liquid chromatography

L56Br-C1 cells were seeded as described for the proliferation assay and, after $24 \mathrm{~h}$ of treatment, cells were harvested, counted, pelleted and stored at $-20{ }^{\circ} \mathrm{C}$ until analysis. Chromatographic separation and quantitative determination of the polyamines in cell extracts in $0.2 \mathrm{M}$ perchloric acid were carried out using high performance liquid chromatography (Hewlett Packard 1100) with $\theta$-phthaldialdehyde as the reagent (Seiler and Knodgen 1985).

Spermidine/spermine $N^{1}$-acetyltransferase activity assay

L56Br-C1 cells were seeded as described for the proliferation assay and, after $24 \mathrm{~h}$ of treatment, cells were harvested, counted, pelleted and stored at $-80{ }^{\circ} \mathrm{C}$ until analysis. The samples were sonicated in $50 \mathrm{mM}$ Tris- $\mathrm{HCl}$ (pH 7.5) containing $0.25 \mathrm{M}$ sucrose. The spermidine/ spermine $N^{1}$-acetyltransferase (SSAT) activity was determined in the sonicates by measuring the synthesis of ${ }^{14}[\mathrm{C}]$ acetylspermidine after incubation of the cell extracts with ${ }^{14}[\mathrm{C}]$ acetyl-coenzyme $\mathrm{A}$ and spermidine, as previously described (Matsui et al. 1981).

Cell cycle phase distribution and cell death analysis by flow cytometry

MCF-10A, JIMT-1 and L56Br-C1 cells were seeded as described for the proliferation assay and were further prepared for flow cytometric analysis, as previously described (Silva et al. 2013). The cells were analyzed using an Accuri C6 flow cytometer (BD Biosciences, San Jose, CA, USA). For the computerized evaluation of the cell cycle phase distribution and the sub- $\mathrm{G}_{1}$ region, the MultiCycle ${ }^{\circledR}$ software program (Phoenix Flow Systems, CA, USA) was used. The sub- $G_{1}$ region was evaluated as percentage signals in sub- $G_{1}$ in relation to all the signals in the sub- $G_{1}$, $\mathrm{G}_{1}, \mathrm{~S}$ and $\mathrm{G}_{2}$ histograms. The distribution of the cells in $\mathrm{G}_{1}, \mathrm{~S}$ and $\mathrm{G}_{2}$ phases was evaluated in $\%$ of all cells in $\mathrm{G}_{1}, \mathrm{~S}$ and $\mathrm{G}_{2}$.

Identification of the $\mathrm{CD} 44^{+} \mathrm{CD} 24^{-}$putative cancer stem cell population by flow cytometry

JIMT- 1 cells $\left(0.6 \times 10^{6}\right.$ cells $)$ were seeded into $5 \mathrm{ml}$ of medium in Petri dishes $(5 \mathrm{~cm}$ diameter) and, after a $72 \mathrm{~h}$ treatment period, cells were harvested by Accutase to prevent the disruption of the cell surface proteins. Afterward, the live cells were washed three times with $5 \mathrm{ml}$ ice-cold PBS containing $1 \%$ FCS and incubated while shaking for 15 min on ice with the monoclonal antibodies CD44-FITC and CD24-PE. Next, cells were again washed three times with ice-cold PBS containing $1 \%$ FCS and identified based on their expression of the cell surface markers CD44 and CD24 using an Accuri C6 flow cytometer (BD Biosciences, San Jose, CA, USA). The data were analyzed using the CFlow software (BD Biosciences, San Jose, CA, USA).

\section{Colony formation in soft agar}

JIMT-1 and L56Br-C1 cells were seeded and treated as described for the proliferation assay, before reseeding in soft agar at low density. After $72 \mathrm{~h}$ of treatment, cells were trypsinized, counted and resuspended in agarose containing medium ( $0.3 \%$ agarose) at cloning density, i.e., one cell per microliter, and then reseeded $(0.5 \mathrm{ml})$ in 48 -well plates coated with polyHEMA (Cirenajwis et al. 2010). The cells were incubated at $37{ }^{\circ} \mathrm{C}$ in a humidified incubator with 
$5 \% \mathrm{CO}_{2}$ in air for 14 days and colonies were counted in an inverted phase contrast microscope.

Single cell gel electrophoresis assay

The single cell gel electrophoresis (SCGE) assay was performed as previously described (Freiburghaus et al. 2012). Briefly, MCF-10A cells $\left(0.3 \times 10^{6}\right.$ cells $)$ and JIMT-1 and $\mathrm{L} 56 \mathrm{Br}-\mathrm{C} 1$ cells $\left(0.7 \times 10^{6}\right.$ cells $)$ were seeded into $5 \mathrm{ml}$ of medium in Petri dishes $(5 \mathrm{~cm}$ in diameter). After $72 \mathrm{~h}$ of treatment with a $10 \mu \mathrm{M}$ concentration of the tested compounds, cells were harvested and special attention was given to the trypsinization time because trypsin can itself induce DNA damage. Consequently, the time of trypsinization was exactly $13 \mathrm{~min}$ for MCF-10A cells, $10 \mathrm{~min}$ for JIMT-1 cells and 6 min for L56Br-C1 cells.

The comets were investigated and photographed with an epifluorescence microscope (Olympus AX70 equipped with a Nikon DSRI1 camera). Seven to 22 random images were captured for each sample. In each image, all nucleoids were counted by visual inspection. Then, nucleoids with tails were visually counted in each image. A nucleoid with tail was defined as a nucleoid with a visible tail independent of tail size. The percentage of nucleoids with a tail in relation to all nucleoids was calculated. A mean was calculated for the counted nucleoids in all images of each sample. At least 30 nucleoids were scored for each sample. Afterwards, the mean of the samples for each treatment was calculated.

\section{GSH-Glo ${ }^{\mathrm{TM}}$ Glutathione assay}

The GSH assay was performed according to the instructions of the manufacturer (GSH-Glo ${ }^{\mathrm{TM}}$ Glutathione Assay Technical Bulletin TB369). Briefly, cells were trypsinized, counted in a hemocytometer, pelleted and resuspended in cell culture medium. Aliquots of $180 \mu \mathrm{l}$ cell suspension containing 3,000 (MCF-10A), 6,000 (JIMT-1) or 8,000 (L56Br-C1) cells were seeded in the wells of white, opaque flat-bottomed 96-well plates. At $48 \mathrm{~h}$ of drug treatment $(10 \mu \mathrm{M})$, the medium was removed from the plates very carefully. Next, luciferin-NT and glutathione S-transferase were added to GSH-Glo ${ }^{\mathrm{TM}}$ reaction buffer to make GSH$\mathrm{Glo}^{\mathrm{TM}}$ reagent, which was further added to the wells of the plates. Before a 30-min incubation period at room temperature, the plates were swirled gently and briefly. Then, the luciferin detection reagent was added to the wells of the plates, which were again gently and briefly swirled, followed by incubation for $15 \mathrm{~min}$ at room temperature. Finally, luminescence was monitored in a Labsystems iEMS Reader MF (Labsystems Oy, Helsinki, Finland) using the DeltaSoft II v.4.14 software (Biometallics Inc., Princeton, NJ, USA).
Statistical analysis

For the statistical significance evaluation, a one-way ANOVA followed by the Newman-Keuls Multiple Comparison test was used. Differences were considered statistically significant at $p<0.05$.

\section{Results}

\section{MTT reduction}

The reduction of MTT is assumed to be a measure of cell number (Holst and Oredsson 2005) and was initially used to access the toxicity of BENSpm, Pd-BENSpm, CPENSpm or Pt-CPENSpm against the three cell lines investigated, using concentrations that ranged from 0.1 to $100 \mu \mathrm{M}$ and at 24, 48 and $72 \mathrm{~h}$ of treatment (Online Resource 1). The inhibitory concentration $50 \quad\left(\mathrm{IC}_{50}\right)$ obtained after $72 \mathrm{~h}$ of treatment is shown in Table 1. The normal-like MCF-10A cells were least sensitive while the L56Br-C1 cell line was most sensitive. Palladination of BENSPM slightly increased cytotoxicity while platination of CPENSpm greatly decreased cytotoxicity. Based on these data and on previously published data on BENSpm and CPENSpm (McCloskey et al. 2000; Holst and Oredsson 2005; Oredsson et al. 2007; Uimari et al. 2009), we decided to use a $10 \mu \mathrm{M}$ concentration for further studies.

Effect of one treatment cycle on cell proliferation

We first investigated the effect of the compounds on cell proliferation during one treatment cycle (Fig. 1a-c). As also shown in the MTT assay, Pt-CPENSpm was the least cytotoxic compound. Actually, Pt-CPENSpm did not affect proliferation of MCF-10A (Fig. 1a) and L56Br-C1 (Fig. 1c) cells, but slightly inhibited proliferation of

Table 1 Absolute $\mathrm{IC}_{50}$ values $(\mu \mathrm{M})$ of MCF-10A, JIMT-1 and L56$\mathrm{Br}-\mathrm{C} 1$ cells treated for $72 \mathrm{~h}$ with BENSpm, Pd-BENSpm, CPENSpm or Pt-CPENSpm

\begin{tabular}{llll}
\hline Cell line & MCF-10A & JIMT-1 & L56Br-C1 \\
\hline BENSpm & 52.8 & 8.7 & 0.4 \\
Pd-BENSpm & 34.2 & 7.3 & 0.4 \\
CPENSpm & 12.2 & 9.9 & 0.2 \\
Pt-CPENSpm & $>100 \mu \mathrm{M}$ & $>100 \mu \mathrm{M}$ & $>100 \mu \mathrm{M}$ \\
\hline
\end{tabular}

Twenty-four hours after seeding of cells in 96-well plates, the compounds were added in a concentration range of $0.1-100 \mu \mathrm{M}$ and the cells were treated for $72 \mathrm{~h}$ before evaluation using an MTT assay. The data were used to construct dose response curves for the evaluation of absolute $\mathrm{IC}_{50}(n=12)$ 

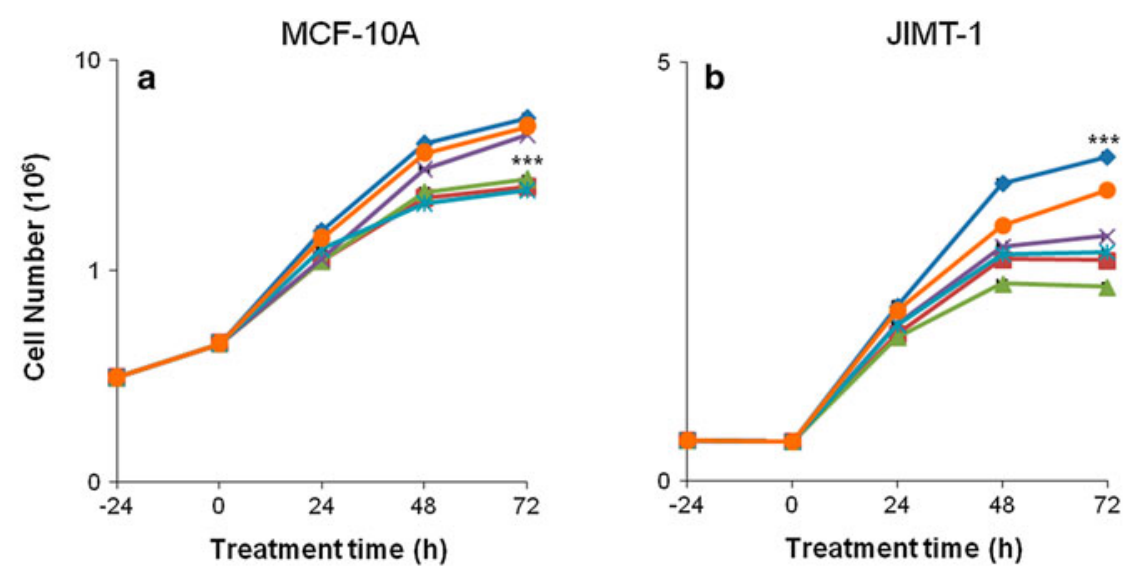

$\mathrm{L} 56 \mathrm{Br}-\mathrm{C} 1$
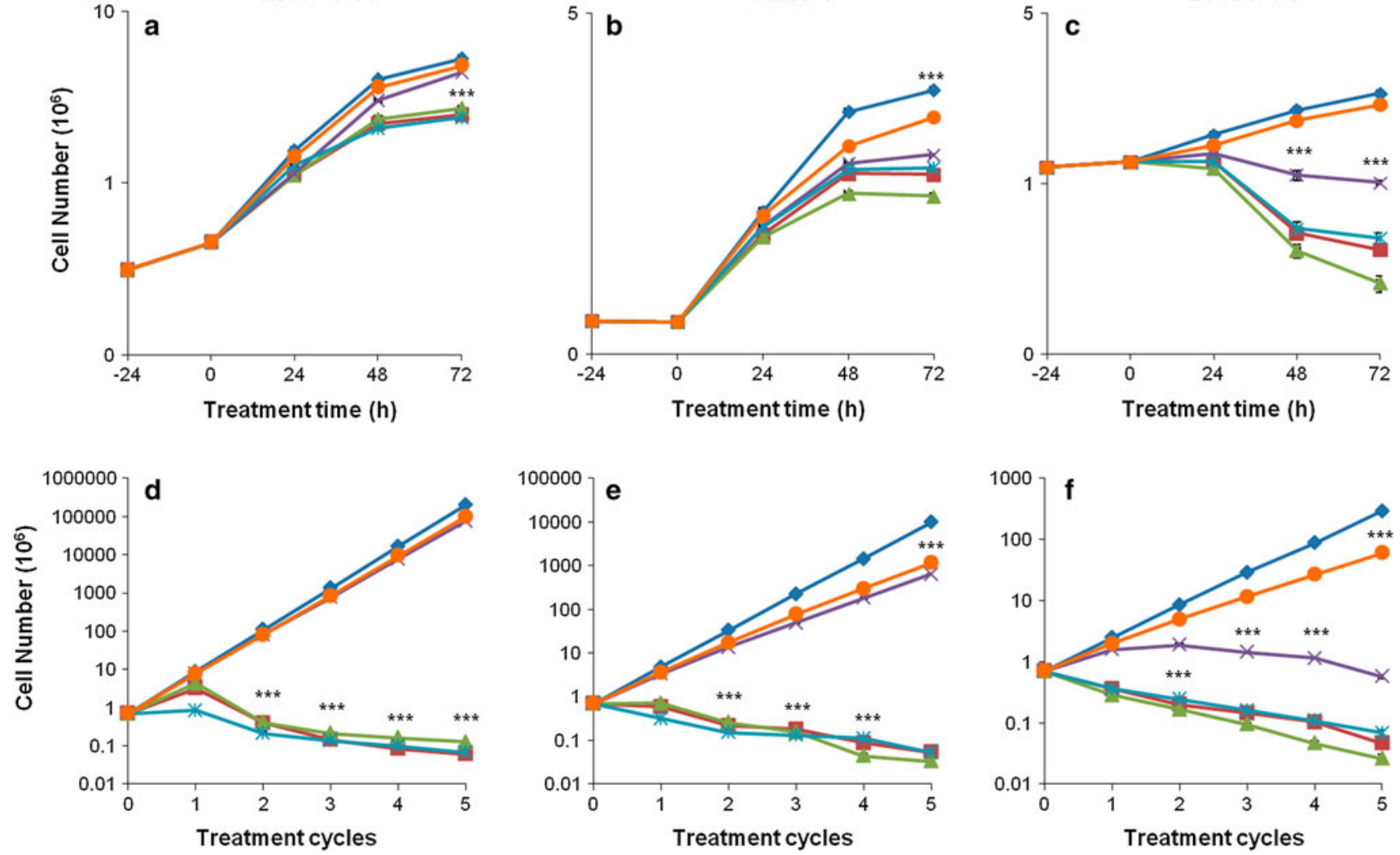

Fig. 1 Effect of BENSpm, Pd-BENSpm, Pd-Spm, CPENSpm or PtCPENSpm treatment on cell proliferation. a-c One treatment cycle. Twenty-four hours after seeding of cells ( $0 \mathrm{~h}$ time of treatment in the figure), the compounds were added to a final concentration of $10 \mu \mathrm{M}$. Cells were harvested by trypsinization and counted in a hemocytometer. The results are presented as mean values $(n=6)$. SEM bars are covered by the symbols. $\mathbf{d}-\mathbf{f}$ Five treatment cycles. Cells were seeded and the compounds were added to the final concentration of $10 \mu \mathrm{M}$, $24 \mathrm{~h}$ after seeding. After $72 \mathrm{~h}$ of treatment, the drug-containing medium was aspirated and drug free culture medium was added. After an additional $72 \mathrm{~h}$ of incubation, cells were harvested by trypsinization and counted in a hemocytometer. These 7 days were defined as one treatment cycle. The cells were reseeded at the same density as at the previous passage and treated with the same drug for the next treatment cycle. All together this was repeated for five treatment cycles. The total recovery time between repeated treatments was $96 \mathrm{~h}$. The results are presented as mean values $(n=3)$. SEM bars are covered by the symbols. Please note that the y-axis has different scales for the different cell lines because of different rates of cell proliferation. $* * * p<0.001$ compared to control for the curves below the symbol. $\triangleleft$ Control, $\square$ BENSpm, $\triangle$ Pd-BENSpm, $\times$ Pd-Spm, $*$ CPENSpm, $\odot$ Pt-CPENSpm
JIMT-1 (Fig. 1b) cells. Pd-Spm treatment did not affect proliferation of MCF-10A cells, while BENSpm, PdBENSpm or CPENSpm treatment slightly reduced the cell numbers at 48 and $72 \mathrm{~h}$ of treatment (Fig. 1a). In L56Br$\mathrm{C} 1$ cells, treatment with BENSpm, Pd-BENSpm or CPENSpm resulted in a decrease in cell number after 48 and $72 \mathrm{~h}$ of treatment compared to the cell number at $24 \mathrm{~h}$ of treatment, implicating cell death (Fig. 1c). PdSpm also resulted in a slight decrease in cell number in L56Br-C1 cells. In JIMT-1 (Fig. 1b) cells, the inhibition of cell proliferation was similar after treatment with BENSpm, Pd-BENSpm, CPENSpm or Pd-Spm. In conclusion, the cell proliferation assay shows that the least sensitive cell line was MCF-10A and the most sensitive one was $\mathrm{L} 56 \mathrm{Br}-\mathrm{C} 1$.
Effect of repeated treatment cycles on cell proliferation

In addition to investigating the effect after one $72 \mathrm{~h}$ treatment cycle, we also evaluated the effect of repeated treatment cycles with $10 \mu \mathrm{M}$ BENSpm, Pd-BENSpm, PdSpm, CPENSpm or Pt-CPENSpm on cell proliferation of MCF-10A, JIMT-1 and L56Br-C1 cells (Fig. 1d-f). The cells were cultivated in cycles with drug treatment for $72 \mathrm{~h}$ followed by a treatment free period of $96 \mathrm{~h}$ in between, for a total number of five cycles. Proliferation of MCF-10A normal-like breast cells was not affected by repeated treatment cycles with either Pt-CPENSpm or Pd-Spm (Fig. 1d), while repeated treatments with these compounds had a somewhat inhibitory effect on the growth of JIMT-1 cells (Fig. 1e). In L56Br-C1 cells, repeated treatments with 

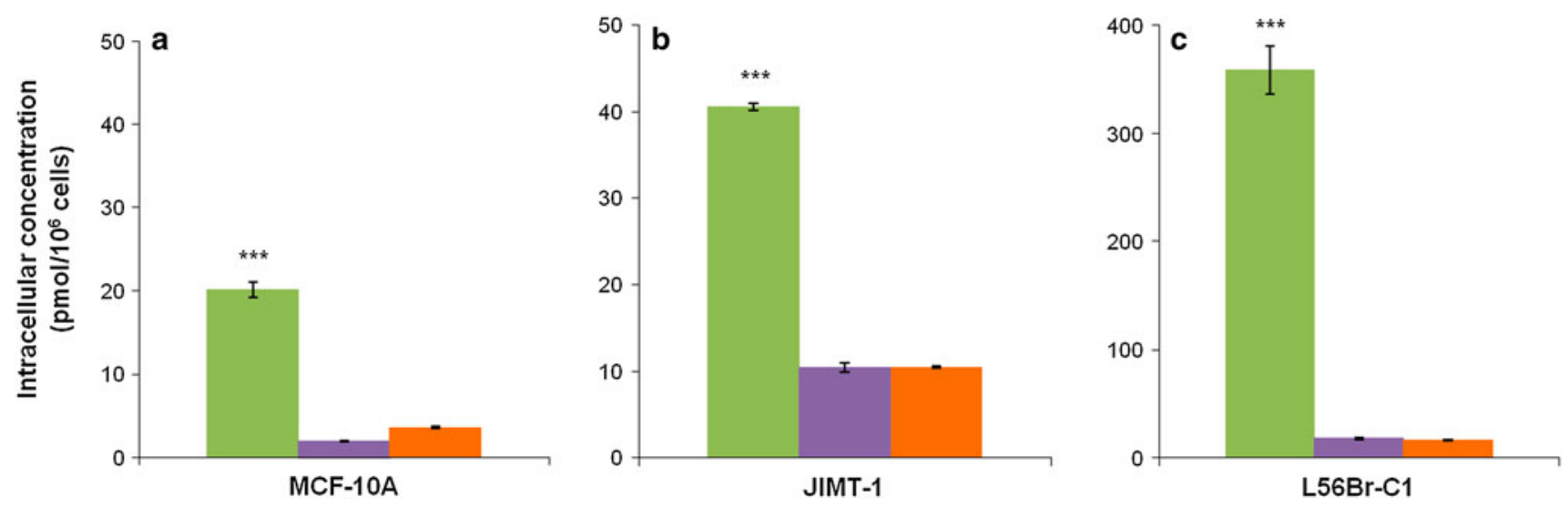

Fig. 2 Intracellular concentration of $\mathrm{Pd}-\mathrm{BENSpm}, \mathrm{Pd}-\mathrm{Spm}$ and PtCPENSpm in MCF-10A, JIMT-1 and L56Br-C1 cells. After $72 \mathrm{~h}$ of treatment with a $10 \mu \mathrm{M}$ concentration of the compounds, cells were harvested, pooled and digested in $\mathrm{HNO}_{3}$. The supernatant was used for analysis of $\mathrm{Pd}(\mathrm{II})$ and $\mathrm{Pt}(\mathrm{II})$ by ICP-MS and the data used to

Pd-Spm resulted in a reduction of cell number after four treatment cycles (Fig. 1f). Repeated treatment with BENSpm, Pd-BENSpm or CPENSpm resulted in a decrease in the cell number, compared to the number of cells seeded at time 0 , in all cell lines (Fig. 1d-f).

Intracellular Pd(II) and $\mathrm{Pt}(\mathrm{II})$ accumulation by inductively-coupled plasma mass spectrometry

ICP-MS was used to quantify the Pd(II) or Pt(II) content in cells treated with $10 \mu \mathrm{M}$ Pd-BENSpm, Pd-Spm or PtCPENSpm for $72 \mathrm{~h}$ and the data were used to calculate the intracellular concentrations of the drugs (Fig. 2). The data demonstrate that the intracellular concentration of $\mathrm{Pd}$ BENSpm was approximately 20,40 and $360 \mathrm{pmol} / 10^{6}$ cells in MCF-10A (Fig. 2a), JIMT-1 (Fig. 2b) and L56BrC1 (Fig. 2c) cells, respectively. The Pd-Spm and PtCPENSpm concentrations were between 2 and $18 \mathrm{pmol} /$ $10^{6}$ cells in the three cell lines, with the highest concentrations in $\mathrm{L} 56 \mathrm{Br}-\mathrm{C} 1$ cells and the lowest concentrations in MCF-10A cells.

\section{Analysis of polyamine levels}

Since $\mathrm{L} 56 \mathrm{Br}-\mathrm{C} 1$ was found to be the most sensitive cell line, we decided to measure the polyamine levels in these cells after $24 \mathrm{~h}$ of treatment with $10 \mu \mathrm{M}$ of BENSpm, Pd-BENSpm, Pd-Spm, CPENSpm or Pt-CPENSpm (Fig. 3). As expected, the putrescine (Fig. 3a), spermidine (Fig. 3b) and spermine (Fig. 3c) contents decreased significantly upon treatment with BENSpm, Pd-BENSpm or CPENSpm, compared to control. Pt-CPENSpm treatment resulted in a minor increase in polyamine levels compared to control, while PdSpm treatment only had a negligible effect (Fig. 3a-c). calculate the intracellular Pd-BENSpm, Pd-Spm and Pt-CPENSpm concentrations in MCF-10A (a), JIMT-1 (b) and L56Br-C1 (c) cells. The results are presented as mean values $(n=3)$ and bars represent $\pm \mathrm{SEM}$. $* * * p<0.001$ compared to $\mathrm{Pd}-\mathrm{Spm}$ or $\mathrm{Pt}$ CPENSpm treatment. | Pd-BENSpm, | Pd-Spm, || Pt-CPENSpm

Spermidine/spermine $N^{1}$-acetyltransferase activity

Since BENSpm or Pd-BENSpm treatment efficiently depleted the polyamines in $\mathrm{L} 56 \mathrm{Br}-\mathrm{C} 1$ cells, we decided to measure the activity of the polyamine catabolic enzyme SSAT. The SSAT activity was very low in untreated L56Br-C1 cells, but increased significantly after treatment with BENSpm, Pd-BENSpm or CPENSpm (Table 2). The increase in SSAT activity was twice as high in cells treated with BENSpm or Pd-BENSpm than in CPENSpm-treated cells. SSAT activity was not detected in Pd-Spm- or PtCPENSpm-treated cells.

Cell cycle phase distribution and cell death

Since the various compounds used in the present study were shown to affect cell proliferation differently, we analyzed the effect of BENSpm, Pd-BENSpm, Pd-Spm, CPENSpm or Pt-CPENSpm on cell cycle phase distribution as well as on cell death using flow cytometry (FCM). Cells were sampled for analysis of the cell cycle phase distribution at 24,48 and $72 \mathrm{~h}$ of treatment, but only data for $48 \mathrm{~h}$ of treatment are shown in Table 3, since they show the major conclusions.

The data show that the only cell line in which the percentage of cells in the sub- $\mathrm{G}_{1}$ region, which reflects cell death, increased substantially was the L56Br-C1 cell line (Table 3). In L56Br-C1 cells, cell death was so prominent that is was not possible to evaluate the DNA histograms at 48 and $72 \mathrm{~h}$ of treatment. L56Br-C1 cells have a high degree of spontaneous apoptotic cell death, which is obvious in Table 3 where the sub- $\mathrm{G}_{1}$ region in control cells is around $20 \%$ (Hegardt et al. 2002). No cell death was observed in MCF-10A and JIMT-1 cells. 


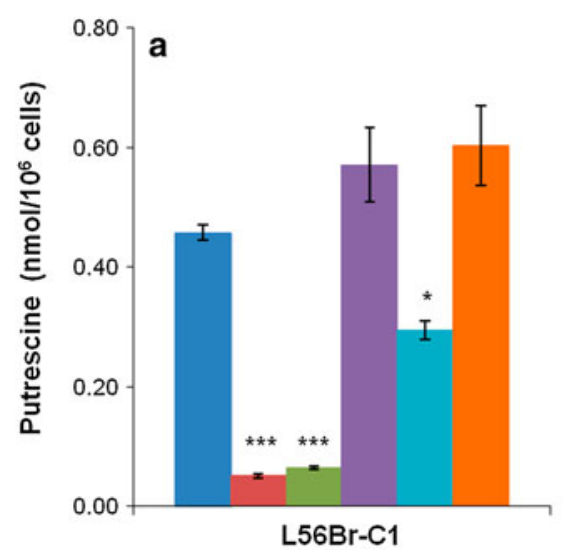

Fig. 3 Effect of BENSpm, Pd-BENSpm, Pd-Spm, CPENSpm or PtCPENSpm treatment on the polyamine content in $\mathrm{L} 56 \mathrm{Br}-\mathrm{C} 1$ cells. After $24 \mathrm{~h}$ of treatment with a $10 \mu \mathrm{M}$ concentration of the compounds, cells were harvested, counted in a hemocytometer and then putrescine (a), spermidine (b) and spermine (c) contents were
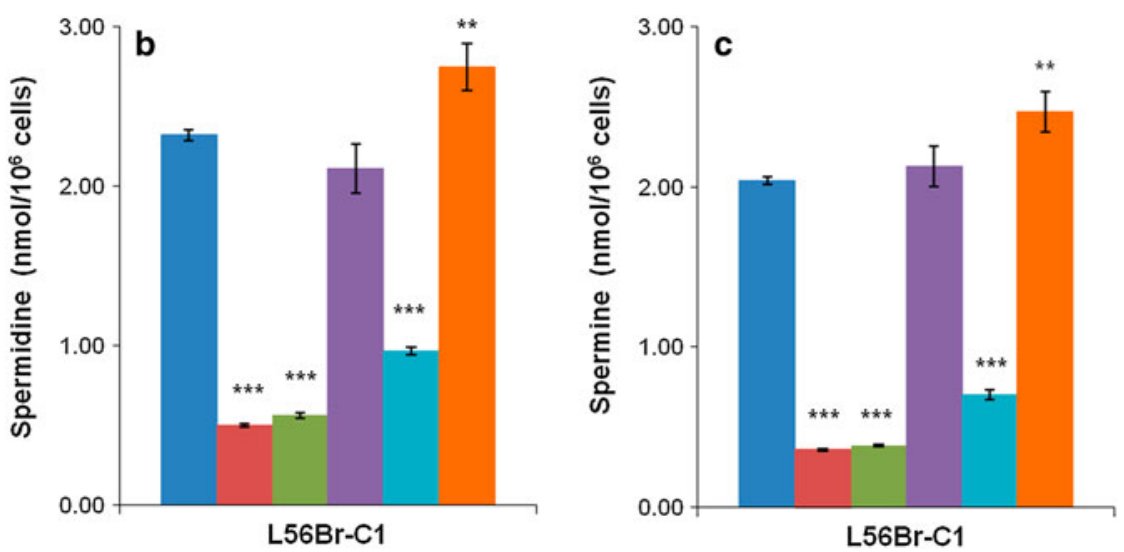

determined by HPLC. The results are presented as mean values $(n=3)$ and bars represent \pm SEM. When not visible, the bars are covered by the symbols. * $p<0.05$ compared to control; ** $p<0.01$ compared to control; $* * * p<0.001$ compared to control. [ Control, I BENSpm, / Pd-BENSpm, / Pd-Spm, / CPENSpm, / Pt-CPENSpm

Table 2 Spermidine/spermine $N^{1}$-acetyltransferase activity in L56Br-C1cells treated with BENSpm, Pd-BENSpm, Pd-Spm, CPENSpm or Pt-CPENSpm for $24 \mathrm{~h}$

\begin{tabular}{ll}
\hline SSAT activity $\left(\mathrm{cpm} / 10^{6}\right.$ cells $)$ & \\
\hline Control & $200 \pm 39$ \\
BENSpm & $32,654 \pm 4,236$ \\
Pd-BENSpm & $40,004 \pm 5,673$ \\
Pd-Spm & n.d. \\
CPENSpm & $15,050 \pm 2,390$ \\
Pt-CPENSpm & n.d.
\end{tabular}

After $24 \mathrm{~h}$ of treatment with a $10 \mu \mathrm{M}$ concentration of the compounds, cells were harvested, counted in a hemocytometer and then the spermidine/spermine $N^{1}$-acetyltransferase activity was determined using a radiometric assay. The results are presented as mean values $(n=6)$ and bars represent \pm SEM

n.d. not detectable

** $p<0.01$ compared to control; *** $p<0.001$ compared to control

In MCF-10A cells, the number of cells in the $\mathrm{G}_{1}$ phase increased from around 50 to $80 \%$ between 24 and $48 \mathrm{~h}$ of treatment with BENSpm, Pd-BENSpm or CPENSpm (Table 3). During the same time period, the percentage of cells in the S phase decreased from 40 to $10 \%$. Less evident changes were found in cell cycle phase distribution of JIMT-1 cells after treatment (Table 3).

Identification of the $\mathrm{CD} 44^{+} \mathrm{CD} 24^{-}$putative cancer stem cell population by flow cytometry

To investigate the effect on the putative breast cancer stem cell (CSC) population, here defined as $\mathrm{CD} 44^{+} \mathrm{CD} 24^{-}$ (Al-Hajj et al. 2003; Cirenajwis et al. 2010), JIMT-1 cells were treated for $72 \mathrm{~h}$ with $10 \mu \mathrm{M}$ BENSpm, Pd-BENSpm, Pd-Spm, CPENSpm or Pt-CPENSpm and the cells were analyzed by FCM after labeling with the CD44-FITC and CD24-PE antibodies. As shown in Fig. 4, treatment with either BENSpm or Pd-BENSpm significantly reduced the $\mathrm{CD} 44^{+} \mathrm{CD} 24^{-}$subpopulation from 50 to $30 \%$ and $33 \%$, respectively, whereas treatment with Pd-Spm, CPENSpm and Pt-CPENSpm resulted in a slight increase in the CD $44^{+} \mathrm{CD} 24^{-}$subpopulation (Fig. 4).

\section{Colony forming efficiency}

The clonogenic assay is designed to measure the ability of single cells to proliferate and form colonies in an anchorage independent manner.

The immortalized normal-like cell line MCF-10A does not form colonies in soft agar and was not used in this assay. In the JIMT-1 and L56Br-C1 breast cancer cell lines, all the treatments decreased the colony forming efficiency (CFE), compared to the control (Table 4). The CFE was similar in JIMT-1 and $\mathrm{L} 56 \mathrm{Br}-\mathrm{C} 1$ control cells, around $30 \%$. Pd-BENSpm treatment was most efficient in reducing the number of colonies and $\mathrm{L} 56 \mathrm{Br}-\mathrm{C} 1$ was the most sensitive cell line to all the treatments (Table 4).

Single cell gel electrophoresis assay

The SCGE assay is a method used to detect DNA damage in single cells and it was used to investigate if the compounds induced DNA strand breaks (Silva et al. 2013).

Table 5 shows the percentage of nucleoids with tails in relation to the total number of nucleoids scored after $72 \mathrm{~h}$ of 
Table 3 Sub-G G $_{1}$ region and cell cycle phase distribution of MCF-10A, JIMT-1 and L56Br-C1 cells treated with BENSpm, Pd-BENSpm, PdSpm, CPENSpm or Pt-CPENSpm for $48 \mathrm{~h}$

\begin{tabular}{|c|c|c|c|c|c|c|}
\hline & Control (\%) & BENSpm (\%) & Pd-BENSpm (\%) & Pd-Spm (\%) & CPENSpm (\%) & Pt-CPENSpm (\%) \\
\hline \multicolumn{7}{|l|}{ MCF-10A } \\
\hline Sub- $\mathrm{G}_{1}$ & $4.3 \pm 0.6$ & $1.5 \pm 0.1$ & $1.7 \pm 0.3$ & $4.6 \pm 0.5$ & $3.3 \pm 0.2$ & $3.5 \pm 0.1$ \\
\hline $\mathrm{G}_{1}$ & $73.0 \pm 1.1$ & $83.9 \pm 0.9$ & $84.9 \pm 0.6$ & $63.4 \pm 0.9$ & $80.4 \pm 0.5$ & $69.3 \pm 0.7$ \\
\hline$S$ & $21.5 \pm 0.7$ & $8.0 \pm 0.5$ & $7.8 \pm 0.4$ & $26.2 \pm 0.7$ & $10.5 \pm 0.4$ & $22.0 \pm 0.8$ \\
\hline $\mathrm{G}_{2}$ & $5.5 \pm 0.4$ & $8.1 \pm 0.4$ & $7.4 \pm 0.4$ & $10.4 \pm 0.7$ & $9.1 \pm 0.6$ & $8.7 \pm 0.3$ \\
\hline \multicolumn{7}{|l|}{ JIMT-1 } \\
\hline Sub-G $G_{1}$ & $2.6 \pm 0.3$ & $2.0 \pm 0.1$ & $2.2 \pm 0.2$ & $2.7 \pm 0.1$ & $2.9 \pm 0.2$ & $3.0 \pm 0.1$ \\
\hline $\mathrm{G}_{1}$ & $53.6 \pm 1.0$ & $61.2 \pm 0.6$ & $62.2 \pm 0.8$ & $53.6 \pm 0.4$ & $68.3 \pm 0.7$ & $67.1 \pm 0.3$ \\
\hline S & $34.4 \pm 0.9$ & $29.7 \pm 0.1$ & $28.3 \pm 0.8$ & $38.0 \pm 0.2$ & $23.1 \pm 0.7$ & $25.2 \pm 0.5$ \\
\hline $\mathrm{G}_{2}$ & $12.0 \pm 0.1$ & $9.1 \pm 0.6$ & $9.5 \pm 0.2$ & $8.4 \pm 0.2$ & $8.6 \pm 0.1$ & $7.7 \pm 0.3$ \\
\hline \multicolumn{7}{|l|}{ L56Br-C1 } \\
\hline Sub-G ${ }_{1}$ & $28.9 \pm 1.6$ & $78.4 \pm 0.5$ & $79.7 \pm 0.5$ & $29.4 \pm 0.5$ & $84.6 \pm 0.5$ & $13.3 \pm 1.3$ \\
\hline $\mathrm{G}_{1}$ & $56.6 \pm 1.2$ & $-^{\mathrm{a}}$ & $-{ }^{\mathrm{a}}$ & $38.3 \pm 2.6$ & $-{ }^{\mathrm{a}}$ & $53.6 \pm 0.7$ \\
\hline$S$ & $36.4 \pm 0.9$ & $-{ }^{\mathrm{a}}$ & $-{ }^{\mathrm{a}}$ & $45.6 \pm 0.9$ & $-{ }^{\mathrm{a}}$ & $37.4 \pm 0.7$ \\
\hline $\mathrm{G}_{2}$ & $7.0 \pm 1.3$ & $-{ }^{\mathrm{a}}$ & $-{ }^{\mathrm{a}}$ & $16.1 \pm 2.2$ & $-{ }^{\mathrm{a}}$ & $9.0 \pm 0.2$ \\
\hline
\end{tabular}

Twenty-four hours after seeding the cells, BENSpm, Pd-BENSpm, Pd-Spm, CPENSpm or Pt-CPENSpm was added to a final concentration of $10 \mu \mathrm{M}$. At 24, 48 and $72 \mathrm{~h}$ of treatment, both detached and attached cells were harvested, pooled and fixed in $70 \%$ ice-cold ethanol. The nuclei were stained with PI and the analysis was performed using flow cytometry. Only results from $48 \mathrm{~h}$ of treatment are shown. The results are presented as mean values $(n=3) \pm$ SEM. The sub- $\mathrm{G}_{1}$ region was evaluated as percentage signals in sub- $\mathrm{G}_{1}$ in relation to all signals in the sub$\mathrm{G}_{1}, \mathrm{G}_{1}, \mathrm{~S}$ and $\mathrm{G}_{2}$ histograms. The distribution of cells in the $\mathrm{G}_{1}, \mathrm{~S}$ and $\mathrm{G}_{2}$ phases was evaluated in $\%$ of all cells in $\mathrm{G}_{1}, \mathrm{~S}$ and $\mathrm{G}_{2}$

${ }^{a}$ In L56Br-C1 cells treated with BENSpm, Pd-BENSpm or CPENSpm, cell death was so prominent that it was not possible to evaluate the distribution of cells in $\mathrm{G}_{1}, \mathrm{~S}$ and $\mathrm{G}_{2}$ phases

treatment. There were fewer nucleoids with tails in control of MCF-10A and JIMT-1 cells, compared to L56Br-C1 cells. All treatments resulted in an increase in the number of nucleoids with a tail in all cell lines, although the increase was most prominent in L56Br-C1 cells. Of the five tested compounds, Pd-BENSpm was the most efficient in increasing the number of nucleoids with tails. Online Resource 2 shows the comets of $\mathrm{L} 56 \mathrm{Br}-\mathrm{C} 1$ cells.

\section{GSH-Glo $^{\mathrm{TM}}$ Glutathione assay}

Since the toxicity of cisplatin has been shown to be dependent on the cellular GSH level (Chen and Kuo 2010), we decided to investigate the GSH level in the cells lines and effects on the level when treating with the compounds.

Table 6 shows that Pd-Spm treatment reduced the GSH level in all cell lines. In fact, in Pd-Spm-treated cells, the level was below the detection limit of the assay and thus the value was set to not detectable (n.d.) Treatment with BENSpm, PdBENSpm or CPENSpm resulted in a marked reduction of the cellular GSH levels. The decrease in cellular GSH was most prominent in the L56Br-C1 cells. Pt-CPENSpm treatment, on the other hand, only slightly reduced or even increased the GSH level, depending on the cell line tested.

In addition to the effects of the various treatments on the GSH level, Table 6 also shows the effects on cell proliferation (given as \% of cells relative to control at $48 \mathrm{~h}$ of treatment). The cell proliferation data are derived from the growth curves shown in Fig. 1a-c. Comparing the GSH levels and cell growth, it is clear that there is no obvious correlation between decrease in GSH and reduction of cell number in any of the cell lines.

\section{Discussion}

Cisplatin was the first Pt-based drug used in cancer therapy but, unfortunately, it exhibits severe off-target effects and cancers often acquire resistance to the drug (Lebwohl and Canetta 1998; Wang and Lippard 2005). In an attempt to overcome these limitations, new metal-based antitumor complexes, particularly $\mathrm{Pd}(\mathrm{II})$ and $\mathrm{Pt}(\mathrm{II})$ polynuclear complexes using polyamines as bridging ligands, have been synthesized over the last decades (Lebwohl and Canetta 1998; Marques et al. 2002; Fiuza et al. 2006, 2011; Soares et al. 2007; Silva et al. 2012).

In the present study, the cytotoxic effects of the metalbased polyamine complexes, Pd-BENSpm, Pd-Spm and PtCPENSpm on two breast cancer cell lines (JIMT-1and L56Br-C1) and one immortalized normal-like breast epithelial cell line (MCF-10A) were analyzed. In general, the normal-like MCF-10A cells were less affected by treatment 

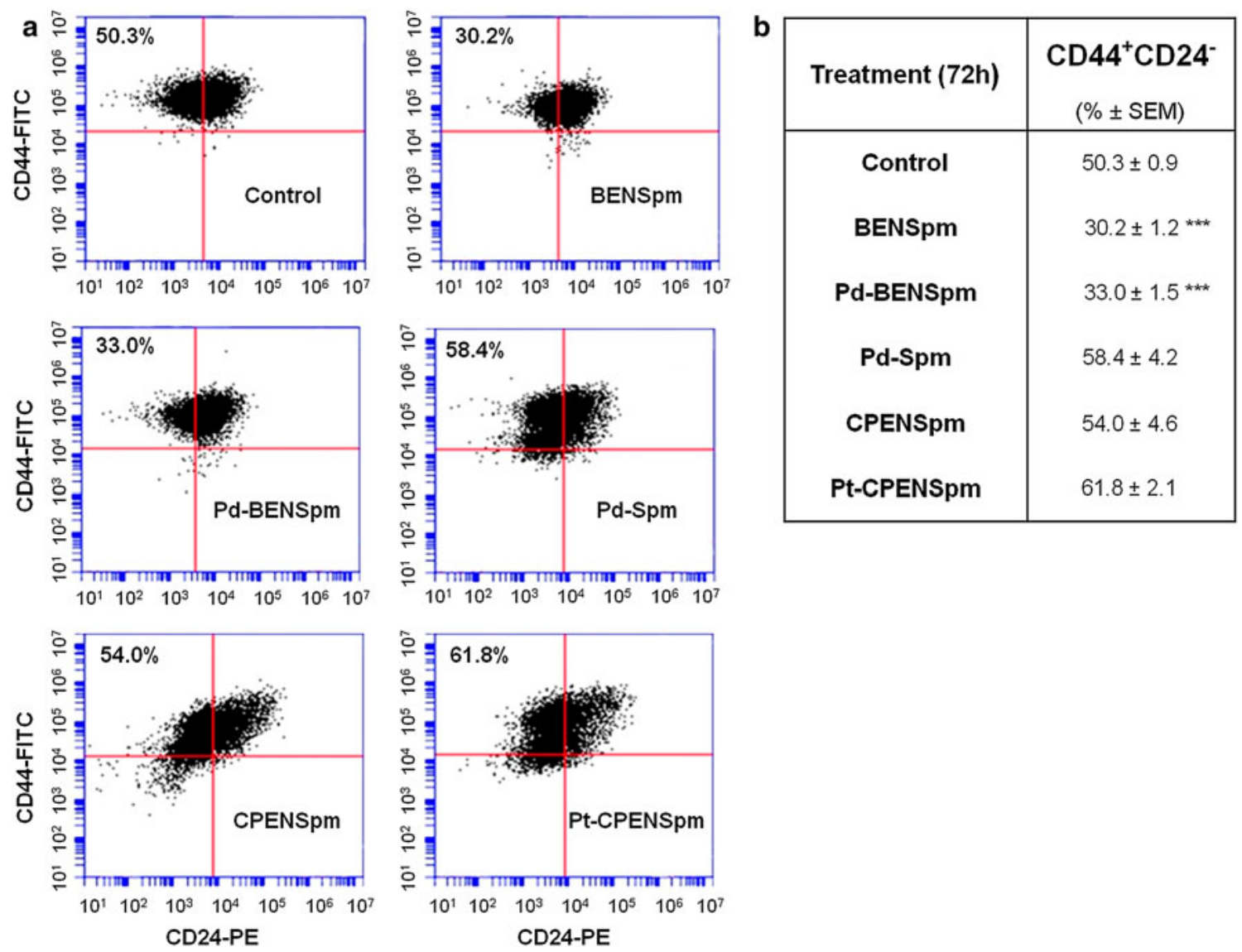

Fig. 4 Effect of BENSpm, Pd-BENSpm, Pd-Spm, CPENSpm or PtCPENSpm treatment on the $\mathrm{CD} 44^{+} \mathrm{CD} 24^{-}$putative cancer stem cell population in JIMT-1 cells. After $72 \mathrm{~h}$ of treatment with a $10 \mu \mathrm{M}$ concentration of the compounds, cells were harvested with Accutase and identified based on their expression of the cell surface markers CD44 and

Table 4 Effects of BENSpm, Pd-BENSpm, Pd-Spm, CPENSpm or Pt-CPENSpm treatment of JIMT-1 and L56Br-C1 cells on the colony forming efficiency in soft agar

\begin{tabular}{llr}
\hline Cell line & \multicolumn{1}{l}{ JIMT-1 } & \multicolumn{1}{l}{ L56Br-C1 } \\
\hline Control (\%) & $29.4 \pm 1.0$ & $32.7 \pm 1.9$ \\
BENSpm (\%) & $15.1 \pm 0.5(51.2)^{* * *}$ & $10.8 \pm 0.5(33.0)^{* * *}$ \\
Pd-BENSpm (\%) & $12.1 \pm 0.3(41.3)^{* * *}$ & $7.8 \pm 0.1(23.7)^{* * *}$ \\
Pd-Spm (\%) & $20.5 \pm 0.3(69.7)^{* * *}$ & $17.0 \pm 1.0(51.8)^{* * *}$ \\
CPENSpm (\%) & $16.4 \pm 0.8(55.7)^{* * *}$ & $11.8 \pm 1.0(36.2)^{* * *}$ \\
Pt-CPENSpm (\%) & $24.1 \pm 0.4(82.1)^{* * *}$ & $24.0 \pm 0.5(73.2)^{* * *}$ \\
\hline
\end{tabular}

Cells were seeded and the compounds $(10 \mu \mathrm{M})$ were added $24 \mathrm{~h}$ later. After $72 \mathrm{~h}$ of treatment, the cells were harvested, counted and reseeded at cloning density in soft agar. Colonies were counted after 14 days of incubation. The results are presented as mean values $(n=3) \pm$ SEM and as percentage of control (in brackets)

*** $p<0.001$ compared to control

with any of the compounds than the cancer cell lines as shown by the higher $\mathrm{IC}_{50}$ value, the lower effects on cell proliferation and on comet formation. In addition, of the
CD24 by flow cytometry. a Representative cytograms of the flow cytometric analysis of cell surface-expressed CD44 and CD24 in the JIMT-1 breast cancer cell line. b Table showing the data obtained with each treatment. The results are presented as percentage of total population $(n=9) \pm$ SEM. $* * * p<0.001$ compared to control

very toxic compounds, BENSpm, CPENSpm and PdBENSpm, the latter, i.e., Pd-BENSpm, showed the lowest relative toxicity in MCF-10A cells, which is promising.

Previous studies have shown that BENSpm and CPENSpm inhibit cell proliferation of breast cancer cell lines (Holst and Oredsson 2005; Oredsson et al. 2007; Cervelli et al. 2010) and our study confirm those data. In addition, we show that repeated treatment cycles further suppresses cell proliferation. Interestingly, platination of CPENSpm clearly induced a marked reduction in toxicity in all the cell lines analyzed in the present study. In contrast, palladination of BENSpm increased the cytotoxic effect of the compound. One cause for the difference in toxicity may be related to cellular uptake, which was significantly higher for Pd-BENSpm than for Pt-CPENSpm. Earlier studies on Pd(II)- or Pt(II)-NSpd complexes showed that the substitution of $\mathrm{Pt}(\mathrm{II})$ for $\mathrm{Pd}(\mathrm{II})$ increased the cytotoxicity of the compound (Silva et al. 2013). However, the difference in cytotoxicity between the Pd(II) complex and the $\mathrm{Pt}(\mathrm{II})$ complex of NSpd was not explained by a 
difference in uptake, thus indicating an alternative mechanism. Furthermore, the use of chelating ligands in this fashion may render a very stable Pt(II) compound with reduced lability relative to its parent compound cisplatin and its palladium counterpart and, therefore, less prone to react with cellular targets.

The cell line that was most sensitive to the compounds was L56Br-C1, which was also found for NSpd, Pd-NSpd and Pt-NSpd (Silva et al. 2013). Pd-BENSpm, BENSpm

Table 5 Effects of treatment with BENSpm, Pd-BENSpm, Pd-Spm, CPENSpm or Pt-CPENSpm on the number of comets, i.e., nucleoids with tails in MCF-10A, JIMT-1 and L56Br-C1 cell lines evaluated by the single cell gel electrophoresis assay

\begin{tabular}{lccc}
\hline Cell line & MCF-10A & JIMT-1 & L56Br-C1 \\
\hline Control & $4.6 \pm 1.0$ & $4.5 \pm 1.5$ & $8.1 \pm 0.8$ \\
BENSpm & $11.0 \pm 1.6^{* *}$ & $18.3 \pm 3.7 *$ & $30.5 \pm 2.4^{* * *}$ \\
Pd-BENSpm & $11.2 \pm 1.0^{* *}$ & $23.8 \pm 4.0 * *$ & $41.2 \pm 3.8^{* * *}$ \\
Pd-Spm & $9.2 \pm 0.9$ & $14.3 \pm 3.0 *$ & $24.2 \pm 2.4^{* *}$ \\
CPENSpm & $11.3 \pm 1.5^{* *}$ & $16.1 \pm 3.9 *$ & $27.2 \pm 2.2^{* * *}$ \\
Pt-CPENSpm & $9.0 \pm 1.6$ & $11.1 \pm 2.0$ & $18.4 \pm 2.1^{*}$
\end{tabular}

Cells were seeded and the compounds $(10 \mu \mathrm{M})$ were added $24 \mathrm{~h}$ later. After $72 \mathrm{~h}$ of treatment, the cells were harvested by trypsinization and the single cell gel electrophoresis assay was performed as previously described. The results show the percentage of nucleoids with tails in relation to the total number of nucleoids scored and are presented as mean values of three independent samples $(n=150$ cells $) \pm$ SEM

$* p<0.05$ compared to control; ** $p<0.01$ compared to control; $* * * p<0.001$ compared to control and CPENSpm were all strongly cytotoxic against $\mathrm{L} 56 \mathrm{Br}$ $\mathrm{C} 1$ cells, as revealed by growth inhibition, increased cell death, decreased CFE, as well as induction of DNA strand breaks. The uptake of Pd-BENSpm was much more efficient in the $\mathrm{L} 56 \mathrm{Br}-\mathrm{C} 1$ cells than in the other cell lines tested, which may partly explain the sensitivity of this cell line to the Pd (II) complex. Another possible explanation for the difference in sensitivity may lie in a different basal level of GSH in the cell lines. The GSH pool was about $50 \%$ lower in L56Br-C1 cells compared to that in MCF10A and JIMT-1 cells. GSH has been shown to be involved in the toxicity of cisplatin. Chen and Kuo (2010) showed that the toxicity of cisplatin was reduced by GSH. Binding of GSH to cisplatin is responsible for metabolic drug inactivation, thereby decreasing its bioavailability at the pharmacological target and hence its antitumor activity (Wu et al. 2013). In addition, cisplatin resistance has sometimes been correlated with a rise in the levels of cellular GSH (Wu et al. 2013).

Interestingly, we found that GSH was not detectable in Pd-Spm-treated MCF-10A, JIMT-1 and L56Br-C1 cells. $\mathrm{Pd}-\mathrm{Spm}$ was presumably efficiently inactivated by binding to $\mathrm{GSH}$, thus resulting in reduced cytotoxicity. Moreover, $\mathrm{Pd}(\mathrm{II})$ is more prone to bind to sulfur atoms than $\mathrm{Pt}(\mathrm{II})$ (Lim 1977). Comparing Pd-Spm with Pd-BENSpm, it may be that the latter is more stable and thus the metal is not free to interact with GSH. The fact that the cell number did not decrease after $48 \mathrm{~h}$ of treatment with Pd-Spm in any of the cell lines may imply efficient synthesis of GSH,

Table 6 Effects of treatment with BENSpm, Pd-BENSpm, Pd-Spm, CPENSpm or Pt-CPENSpm on the levels of glutathione (GSH) in MCF10A, JIMT-1 and L56Br-C1 cell lines, evaluated by the GSH-Glo ${ }^{\text {TM }}$ Glutathione Assay

\begin{tabular}{|c|c|c|c|c|c|c|}
\hline Cell line & Control & BENSpm & Pd-BENSpm & Pd-Spm & CPENSpm & Pt-CPENSpm \\
\hline \multicolumn{7}{|l|}{ MCF-10A } \\
\hline GSH (nmol/10 $10^{6}$ cells) & $34.3 \pm 1.7$ & $25.8 \pm 1.8$ & $26.9 \pm 2.6$ & n.d. & $22.7 \pm 2.5$ & $40.7 \pm 2.5$ \\
\hline GSH ( $\%$ of control) & & $75.1 * * *$ & $78.4 * * *$ & n.d. & $66.2 * * *$ & $118.5^{* *}$ \\
\hline Cell number ( $\%$ of control) & & 55.4 & 58.8 & 75.5 & 52.1 & 90.4 \\
\hline \multicolumn{7}{|l|}{ JIMT-1 } \\
\hline GSH (nmol/10 $10^{6}$ cells $)$ & $30.9 \pm 1.5$ & $17.1 \pm 1.9$ & $7.9 \pm 0.8$ & n.d. & $18.6 \pm 2.4$ & $20.0 \pm 5.8$ \\
\hline GSH ( $\%$ of control) & & $55.1 * * *$ & $25.6^{* * *}$ & n.d. & $60.0 * * *$ & $64.8 * * *$ \\
\hline Cell number ( $\%$ of control) & & 65.9 & 57.6 & 70.8 & 67.7 & 79.4 \\
\hline \multicolumn{7}{|l|}{ L56Br-C1 } \\
\hline GSH (nmol/10 $10^{6}$ cells $)$ & $15.1 \pm 1.0$ & $2.8 \pm 0.4$ & $0.5 \pm 0.5$ & n.d. & $1.0 \pm 0.2$ & $21.3 \pm 4.2$ \\
\hline GSH ( $\%$ of control) & & $18.6^{* * *}$ & $3.0 * * *$ & n.d. & $6.8 * * *$ & $140.3 * * *$ \\
\hline Cell number ( $\%$ of control) & & 19.0 & 14.9 & 41.5 & 20.1 & 87.0 \\
\hline
\end{tabular}

Cells were seeded in white opaque 96-well plates and the compounds were added $24 \mathrm{~h}$ later to a final concentration of $10 \mu \mathrm{M}$. After $48 \mathrm{~h}$ of treatment, the plates were removed from the incubator and the GSH-Glo ${ }^{\mathrm{TM}}$ Glutathione assay was performed according to the instructions of the manufacturer. The results of the GSH assay are presented as nmol/10 $0^{6}$ cells (mean $\left.\pm \mathrm{SD}\right)(n=3)$ and as percentage of control. In Pd-Spmtreated cells, the level was below the detection limit of the assay and thus the value was set to not detectable (n.d.). The data in the row defined as Cell number were derived from the growth curves (Fig. 2a-c). At $48 \mathrm{~h}$ of treatment, the number of cells in each treatment was calculated as $\%$ of control

** $p<0.01$ compared to control; *** $p<0.001$ compared to control 
maintaining at least a low pool, although not detectable, of GSH sufficient for cell proliferation and survival. However, this notion has to be further investigated. Treatment with BENSPM, Pd-BENSpm or CPENSpm lowered the GSH pools but not to the same extent as Pd-Spm, implying that these compounds were not inactivated by GSH to the same extent as was $\mathrm{Pd}-\mathrm{Spm}$. The $\mathrm{Pd}-\mathrm{BENSpm}$ chelate thus appears to be more stable that its analogue $\mathrm{Pd}-\mathrm{Spm}$, possibly due to the presence of the extra $-\mathrm{CH}_{2} \mathrm{CH}_{3}$ groups at the terminal nitrogens of the polyamine ligand. Moreover, this additional alkylation renders the complex more lipophilic, which can be an advantage for efficiently crossing the cellular and nuclear membranes in its way to the biological target (DNA). Regarding the GSH lowering activity of Pd-Spm, it may be exploited in the search for anticancer redox chemotherapeutics (Wu et al. 2013).

$\mathrm{Pd}-\mathrm{Spm}$ has previously been demonstrated to be cytotoxic against the breast cancer cell lines MCF-7 and MDAMB-231 (Fiuza et al. 2011), as well as the human oral squamous carcinoma cell line HSC-3 (Soares et al. 2007). In those studies, the effect of Pd-Spm seemed to be irreversible. No recovery was observed after withdrawal of the drug. Nevertheless, as shown in the present study, the cytotoxic effect of $\mathrm{Pd}-\mathrm{Spm}$ was, at least, partly reversible in the cell lines JIMT-1 and MCF-10A.

Breast cancer is a heterogeneous disease, composed of tumor cells with different gene expressions and phenotypes (Kao et al. 2009; Kim et al. 2012). The cell surface markers CD44 and CD24 are adhesion molecules and $\mathrm{CD} 44^{+} \mathrm{CD} 24^{-}$cells were suggested to be breast cancer stem cells (Al-Hajj et al. 2003). We have previous shown that treatment with the polyamine analogue PG-11047 reduced the putative $\mathrm{CD} 44^{+} \mathrm{CD} 24^{-} \mathrm{CSC}$ population in JIMT-1 cells and decreased their CFE (Cirenajwis et al. 2010). BENSpm, which is a polyamine analogue closely related to PG-11047, also reduced the CSC population evaluated by FCM and the CSC reducing effect was retained to a similar degree by $\mathrm{Pd}-\mathrm{BENSpm}$ treatment (no significant difference was obtained between BENSpm and Pd-BENSpm). Although the antiproliferative effect of CPENSpm treatment was very much similar to that of BENSpm and Pd-BENSpm treatments, there was no effect on the putative $\mathrm{CD} 44^{+} \mathrm{CD} 24^{-} \mathrm{CSC}$ population. In fact, it increased compared to control. Interestingly, all three compounds resulted in similar decrease in CFE. Thus, the CFE was markedly reduced, whereas the putative CD $44^{+} \mathrm{CD} 24^{-}$CSC population was not, after treatment with CPENSpm. Moreover, Pt-CPENSpm treatment resulted in an increased putative $\mathrm{CD} 44^{+} \mathrm{CD} 24^{-} \mathrm{CSC}$ population, in spite of a decrease in the CFE, compared to control. Thus, the data support the notion that other factors than only CD44 positivity and CD24 negativity define CSCs (Ricardo et al. 2011). Also, we did the CFE in the presence of FCS, which may support the colony formation by progenitor cells and not only by CSCs. Only CSCs are supposed to form colonies under serum free conditions (Ponti et al. 2005; Fillmore and Kuperwasser 2008), although our notion is that this is not clearly proven.

The generally accepted mechanism of action for this type of metal-based antineoplastic agents is the covalent binding of the metal center [in this case either $\mathrm{Pt}(\mathrm{II})$ or $\operatorname{Pd}(\mathrm{II})]$ to DNA, particularly to the $\mathrm{N}_{7}$ of the purine bases. Thus, a change in structure, and/or in the nature of the metal center, is expected to affect the compound's efficiency, as observed in this study. Moreover, a change in DNA conformation may also affect the binding of the metal to the DNA. Although, the exact roles of the polyamines are not known it is generally believed that they are important for the DNA conformation. Both BENSpm and CPENSpm have been shown to efficiently deplete cells of their polyamines by down-regulating polyamine biosynthetic enzymes as well as inducing the enzyme catalyzing the initial step in polyamine catabolism, namely SSAT (Davidson et al. 1999; Wolff et al. 2003; Casero and Woster 2009). Interestingly, as shown in the present study, there was a clear correlation between the degree of cytotoxicity and capacity to decrease cellular polyamine levels (and induce SSAT) among the various $\mathrm{Pd}(\mathrm{II})$ and $\mathrm{Pt}(\mathrm{II})$ polyamine complexes. Thus, it is conceivable that a depletion of polyamines may affect DNA conformation in a way that facilitates the covalent binding of the metal center to the DNA.

A close statistical comparison (not shown) between BENSpm and Pd-BENSpm showed that the latter was indeed somewhat more cytotoxic than the former. The cell number was significantly lower in Pd-BENSpm-treated cultures after 48 and $72 \mathrm{~h}$ of treatment than in BENSpmtreated cultures, in all breast cancer cell lines. Pd-BENSpm treatment reduced the CFE significantly more than BENSpm treatment did. Pd-BENSpm treatment resulted in significantly more comets in the SCGE assay than did BENSpm treatment in the two cancer cell lines JIMT-1 and L56Br-C1, but not in MCF-10A cells. Pd-BENSpm treatment also reduced the GSH level significantly more than BENSpm treatment in the two cancer cell lines. Thus, although the difference between BENSpm and Pd-BENSpm is small, Pd-BENSpm showed slightly higher toxicity against cancer cells and thus may be of some importance for further design of new metal-based polyamine analogues.

\section{Conclusion}

In conclusion, the present paper demonstrates that the $\mathrm{Pd}$ BENSpm complex may be regarded as a promising 
inorganic agent to be used for the development of new chemotherapeutic approaches against breast cancer, due to its slightly higher cancer cell toxicity together with a lower toxicity in the normal-like cell line.

Acknowledgments The authors wish to thank Ewa Dahlberg for expert technical assistance and Dr. Patrick Woster for kindly providing the polyamine analogues BENSpm and CPENSpm. The authors acknowledge financial support from the Gunnar Nilsson Cancer Foundation and from the Portuguese Foundation for Science and Technology-SFRH/BD/46364/2008, Projects PTDC/QUI/ 66701/2006 (co-financed by the European Community fund FEDER) and Pest-OE/Qui/UIOO700/2011.

Conflict of interest The authors declare that they have no conflict of interests.

Open Access This article is distributed under the terms of the Creative Commons Attribution License which permits any use, distribution, and reproduction in any medium, provided the original author(s) and the source are credited.

\section{References}

Al-Hajj M, Wicha, Benito-Hernandez A, Morrison SJ, Clarke MF (2003) Prospective identification of tumorigenic breast cancer cells. Proc Natl Acad Sci USA 100(7):3983-3988. doi:10.1073/ pnas.0530291100

Brabec V, Kasparkova J (2005) Modifications of DNA by platinum complexes. Relation to resistance of tumors to platinum antitumor drugs. Drug resist updates: reviews and commentaries in antimicrobial and anticancer. Chemotherapy 8(3):131-146. doi:10.1016/j.drup.2005.04.006

Casero RA Jr, Woster PM (2009) Recent advances in the development of polyamine analogues as antitumor agents. J Med Chem 52(15):4551-4573. doi:10.1021/jm900187v

Cervelli M, Bellavia G, Fratini E, Amendola R, Polticelli F, Barba M, Federico R, Signore F, Gucciardo G, Grillo R, Woster PM, Casero RA Jr, Mariottini P (2010) Spermine oxidase (SMO) activity in breast tumor tissues and biochemical analysis of the anticancer spermine analogues BENSpm and CPENSpm. BMC Cancer 10:555. doi:10.1186/1471-2407-10-555

Chen HH, Kuo MT (2010) Role of glutathione in the regulation of cisplatin resistance in cancer chemotherapy. Met Based Drugs. doi:10.1155/2010/430939

Cirenajwis H, Smiljanic S, Honeth G, Hegardt C, Marton LJ, Oredsson SM (2010) Reduction of the putative CD44 + CD24breast cancer stem cell population by targeting the polyamine metabolic pathway with PG11047. Anticancer Drugs 21(10): 897-906. doi:10.1097/CAD.0b013e32833f2f77

Davidson NE, Hahm HA, McCloskey DE, Woster PM, Casero RA Jr (1999) Clinical aspects of cell death in breast cancer: the polyamine pathway as a new target for treatment. Endocr Relat Cancer 6(1):69-73

Esteban-Fernandez D, Moreno-Gordaliza E, Canas B, Palacios MA, Gomez-Gomez MM (2010) Analytical methodologies for metallomics studies of antitumor Pt-containing drugs. Metallomics Integr Biometal Sci 2(1):19-38. doi:10.1039/b911438f

Fillmore CM, Kuperwasser C (2008) Human breast cancer cell lines contain stem-like cells that self-renew, give rise to phenotypically diverse progeny and survive chemotherapy. Breast Cancer Res 10(2):R25. doi:10.1186/bcr1982
Fiuza SM, Amado AM, Oliveira PJ, Sardão VA, Batista De Carvalho LAE, Marques MPM (2006) Pt(II) vs Pd(II) polyamine complexes as new anticancer drugs: a structure-activity study. Lett Drug Des Discov 3(3):149-151

Fiuza SM, Holy J, Batista de Carvalho LA, Marques MP (2011) Biologic activity of a dinuclear Pd (II)-spermine complex toward human breast cancer. Chem Biol Drug Des 77(6):477-488. doi:10.1111/j.1747-0285.2011.01081.x

Freiburghaus C, Lindmark-Mansson H, Paulsson M, Oredsson S (2012) Reduction of ultraviolet light-induced DNA damage in human colon cancer cells treated with a lactoferrin-derived peptide. J Dairy Sci 95(10):5552-5560. doi:10.3168/jds.20115279

Hegardt C, Johannsson OT, Oredsson SM (2002) Rapid caspasedependent cell death in cultured human breast cancer cells induced by the polyamine analogue $\mathrm{N}(1), \mathrm{N}$ (11)-diethylnorspermine. Eur J Biochem/FEBS 269(3):1033-1039

Hegmans A, Kasparkova J, Vrana O, Kelland LR, Brabec V, Farrell NP (2008) Amide-based prodrugs of spermidine-bridged dinuclear platinum. Synthesis, DNA binding, and biological activity. J Med Chem 51(7):2254-2260. doi:10.1021/jm070813z

Holst CM, Oredsson SM (2005) Comparison of three cytotoxicity tests in the evaluation of the cytotoxicity of a spermine analogue on human breast cancer cell lines. Toxicol In Vitro Int J Publ Assoc BIBRA 19(3):379-387. doi:10.1016/j.tiv.2004.10.005

Iacomino G, Picariello G (1823) D'Agostino L (2012) DNA and nuclear aggregates of polyamines. Biochim Biophys Acta 10:1745-1755. doi:10.1016/j.bbamcr.2012.05.033

Johannsson OT, Staff S, Vallon-Christersson J, Kytola S, Gudjonsson T, Rennstam K, Hedenfalk IA, Adeyinka A, Kjellen E, Wennerberg J, Baldetorp B, Petersen OW, Olsson H, Oredsson S, Isola J, Borg A (2003) Characterization of a novel breast carcinoma xenograft and cell line derived from a BRCA1 germline mutation carrier. Lab Invest A J Tech Methods Pathol 83(3):387-396

Kao J, Salari K, Bocanegra M, Choi YL, Girard L, Gandhi J, Kwei KA, Hernandez-Boussard T, Wang P, Gazdar AF, Minna JD, Pollack JR (2009) Molecular profiling of breast cancer cell lines defines relevant tumor models and provides a resource for cancer gene discovery. PLoS One 4(7):e6146. doi:10.1371/journal. pone.0006146

Kim J, Villadsen R, Sorlie T, Fogh L, Gronlund SZ, Fridriksdottir AJ, Kuhn I, Rank F, Wielenga VT, Solvang H, Edwards PA, Borresen-Dale AL, Ronnov-Jessen L, Bissell MJ, Petersen OW (2012) Tumor initiating but differentiated luminal-like breast cancer cells are highly invasive in the absence of basal-like activity. Proc Natl Acad Sci USA 109(16):6124-6129. doi:10. 1073/pnas. 1203203109

Lebwohl D, Canetta R (1998) Clinical development of platinum complexes in cancer therapy: an historical perspective and an update. Eur J Cancer 34(10):1522-1534

Lim MC (1977) Mixed-ligand complexes of palladium(Ii).1. diaqua(ethylenediamine)palladium(Ii) complexes of glycylglycine and glycinamide. J Chem Soc Dalton 1:15-17. doi:10.1039/ Dt9770000015

Marques MP, Girao T, De Pedroso Lima MC, Gameiro A, Pereira E, Garcia P (2002) Cytotoxic effects of metal complexes of biogenic polyamines. I. Platinum(II) spermidine compounds: prediction of their antitumour activity. Biochim Biophys Acta 1589(1):63-70

Matsui I, Wiegand L, Pegg AE (1981) Properties of spermidine $\mathrm{N}$-acetyltransferase from livers of rats treated with carbon tetrachloride and its role in the conversion of spermidine into putrescine. J Biol Chem 256(5):2454-2459

McCloskey DE, Woster PM, Casero RA Jr, Davidson NE (2000) Effects of the polyamine analogues N1-ethyl-N11- 
((cyclopropyl)methyl)-4,8-diazaundecane and N1-ethylN-11((cycloheptyl)methyl)-4,8-diazaundecane in human prostate cancer cells. Clin Cancer Res 6(1):17-23

Miklasova N, Fischer-Fodor E, Lonnecke P, Tomuleasa CI, Virag P, Schrepler MP, Miklas R, Dumitrescu LS, Hey-Hawkins E (2012) Antiproliferative effect of novel platinum(II) and palladium(II) complexes on hepatic tumor stem cells in vitro. Eur J Med Chem 49:41-47. doi:10.1016/j.ejmech.2011.12.001

Oredsson SM, Alm K, Dahlberg E, Holst CM, Johansson VM, Myhre L, Soderstjerna E (2007) Inhibition of cell proliferation and induction of apoptosis by $\mathrm{N}(1)$, N(11)-diethylnorspermineinduced polyamine pool reduction. Biochem Soc Trans 35(Pt 2):405-409. doi:10.1042/BST0350405

Palmer AJ, Wallace HM (2010) The polyamine transport system as a target for anticancer drug development. Amino Acids 38(2):415-422. doi:10.1007/s00726-009-0400-2

Pasini A, Caldarera CM, Giordano E (2013) Chromatin remodeling by polyamines and polyamine analogs. Amino Acids. doi:10. 1007/s00726-013-1550-9

Pegg AE (1988) Polyamine metabolism and its importance in neoplastic growth and a target for chemotherapy. Cancer Res 48(4):759-774

Ponti D, Costa A, Zaffaroni N, Pratesi G, Petrangolini G, Coradini D, Pilotti S, Pierotti MA, Daidone MG (2005) Isolation and in vitro propagation of tumorigenic breast cancer cells with stem/ progenitor cell properties. Cancer Res 65(13):5506-5511. doi:10.1158/0008-5472.CAN-05-0626

Ricardo S, Vieira AF, Gerhard R, Leitao D, Pinto R, CameselleTeijeiro JF, Milanezi F, Schmitt F, Paredes J (2011) Breast cancer stem cell markers CD44, CD24 and ALDH1: expression distribution within intrinsic molecular subtype. J Clin Pathol 64(11):937-946. doi:10.1136/jcp.2011.090456

Rosenberg B, Vancamp L, Krigas T (1965) Inhibition of cell division in Escherichia coli by electrolysis products from a platinum electrode. Nature 205:698-699

Seiler N (2005) Pharmacological aspects of cytotoxic polyamine analogs and derivatives for cancer therapy. Pharmacol Ther 107(1):99-119. doi:10.1016/j.pharmthera.2005.02.001

Seiler N, Knodgen B (1985) Determination of polyamines and related-compounds by reversed-phase high-performance liquidchromatography-improved separation systems. J Chromatogr 339(1):45-57

Silva TM, Oredsson S, Persson L, Woster P, Marques MP (2012) Novel Pt(II) and Pd(II) complexes with polyamine analogues: synthesis and vibrational analysis. J Inorg Biochem 108:1-7. doi:10.1016/j.jinorgbio.2011.11.021

Silva T, Andersson S, Sukumaran S, Marques M, Persson L, Oredsson S (2013) Norspermidine and novel Pd(II) and Pt(II) polynuclear complexes of norspermidine as potential antineoplastic agents against breast cancer. PLoS One 8(2):e55651. doi:10.1371/ journal.pone.0055651

Soares AS, Fiuza SM, Gonçalves MJ, Batista de Carvalho LAE, Marques MPM, Urbano AM (2007) Effect of the metal center on the antitumor activity of the analogous dinuclear spermine chelates $(\mathrm{PdCl} 2) 2$ (spermine) and $(\mathrm{PtCl} 2) 2$ (spermine). Lett Drug Des Discov 4(7):460-463

Traquete R, Ghani RA, Phanstiel O, Wallace HM (2013) Ant 4,4, a polyamine-anthracene conjugate, induces cell death and recovery in human promyelogenous leukemia cells (HL-60). Amino Acids 44:1193-1203. doi:10.1007/s00726-012-1452-2

Uimari A, Keinanen TA, Karppinen A, Woster P, Uimari P, Janne J, Alhonen L (2009) Spermine analogue-regulated expression of spermidine/spermine N1-acetyltransferase and its effects on depletion of intracellular polyamine pools in mouse fetal fibroblasts. Biochem J 422(1):101-109. doi:10.1042/BJ2009 0411

Ulukaya E, Ari F, Dimas K, Ikitimur EI, Guney E, Yilmaz VT (2011) Anti-cancer activity of a novel palladium(II) complex on human breast cancer cells in vitro and in vivo. Eur $\mathrm{J}$ Med Chem 46(10):4957-4963. doi:10.1016/j.ejmech.2011.07.055

Wallace HM, Fraser AV, Hughes A (2003) A perspective of polyamine metabolism. Biochem J 376(Pt 1):1-14. doi:10. 1042/BJ20031327

Wang D, Lippard SJ (2005) Cellular processing of platinum anticancer drugs. Nat Rev Drug Discov 4(4):307-320. doi:10. 1038/nrd1691

Wolff AC, Armstrong DK, Fetting JH, Carducci MK, Riley CD, Bender JF, Casero RA Jr, Davidson NE (2003) A Phase II study of the polyamine analog N1, N11-diethylnorspermine (DENSpm) daily for five days every 21 days in patients with previously treated metastatic breast cancer. Clin Cancer Res 9(16 Pt 1):5922-5928

Wu WJ, Zhang Y, Zeng ZL, Li XB, Hu KS, Luo HY, Yang J, Huang $\mathrm{P}, \mathrm{Xu}$ RH (2013) Beta-phenylethyl isothiocyanate reverses platinum resistance by a GSH-dependent mechanism in cancer cells with epithelial-mesenchymal transition phenotype. Biochem Pharmacol 85(4):486-496. doi:10.1016/j.bcp.2012.11.017 